\title{
The spruce budworm, a potential threat for Norway spruce in eastern Canada?
}

\author{
by Richard Berthiaume ${ }^{1 *}$, Christian Hébert ${ }^{2}$, Alain Dupont ${ }^{3}$, Martin Charest ${ }^{1}$ and Éric Bauce ${ }^{1}$
}

\begin{abstract}
Norway spruce, an exotic tree species in North America, was largely used in reforestation programs in the province of Québec between 1972 and 1990. Several of these plantations are now reaching their commercial maturity and the resurgence of spruce budworm outbreak is a reminder that the potential threat of this damaging defoliator for Norway spruce still remains unknown. We used two life-history traits, pupal weight and overwintered larval $\left(\mathrm{L}_{2}\right)$ weight, to compare spruce budworm biological performance on Norway spruce, white spruce and black spruce. Pupae collected on Norway spruce and overwintered larvae produced by parents that fed on Norway spruce were heavier than those coming from black spruce. Spruce budworm performance was similar on Norway and white spruce, showing similar suitability and suggesting that it can represent a potential threat for Norway spruce plantations established after the last spruce budworm outbreak in eastern North America.
\end{abstract}

Key words: Norway spruce, black spruce, white spruce, spruce budworm, overwintered larvae weight, pupal weight

\section{RÉSUMÉ}

L'épinette de Norvège, une espèce d'arbre exotique en Amérique du Nord, a été grandement utilisée dans les programmes de reboisement de la province de Québec entre 1972 et 1990. Plusieurs de ces plantations commencent à atteindre leur maturité commerciale et la résurgence d'une épidémie de la tordeuse des bourgeons de l'épinette rappelle que le danger potentiel de ce défoliateur pour l'épinette de Norvège demeure toujours inconnu. Nous avons utilisé deux traits du cycle vital de l'insecte, le poids des chrysalides et le poids des larves hivernantes $\left(L_{2}\right)$ pour comparer la performance biologique de la tordeuse sur l'épinette de Norvège, l'épinette blanche et l'épinette noire. Les chrysalides récoltées sur l'épinette de Norvège et les larves hivernantes produites par des insectes qui avaient mangé de l'épinette de Norvège étaient plus lourdes que celles qui s'étaient alimentées sur l'épinette noire. La performance de la tordeuse sur l'épinette de Norvège était semblable à celle mesurée sur l'épinette blanche, montrant que ces essences sont comparables en terme de convenance de l'hôte pour la tordeuse. Ces résultats suggèrent que la tordeuse des bourgeons de l'épinette peut représenter un danger potentiel pour les plantations d'épinette de Norvège établies après la dernière épidémie dans l'est de l'Amérique du Nord.

Mots-clés : épinette de Norvège, épinette noire, épinette blanche, tordeuse des bourgeons de l'épinette, poids des larves hivernantes, poids des chrysalides

\section{Introduction}

The spruce budworm, Choristoneura fumiferana (Clem.), (Lepidoptera: Tortricidae) is the most important defoliator of coniferous forests in North America. Significant damage occurs when larvae defoliate the current year foliage of balsam fir (Abies balsamea L. Mill.) and of various spruce species (Picea spp.) (Blais 1983; MacLean 1984; Rauchfuss and Ziegler 2011). Historically, balsam fir stands have been more affected by spruce budworm outbreaks than white spruce (Picea glauca (Moench) Voss) and black spruce (Picea mariana (Mill.) B.S.P.) stands (MacLean 1980, 1984; Solomon et al. 2003; Hennigar et al. 2008; Navaro et al. 2018). Throughout the last spruce budworm outbreak (1968-1992), which was considered as the worst of the last century (MacLean 1984; Navarro et al. 2018), severely affected stands were salvaged and eventually reforested with different spruce species, including white spruce, black spruce, and Norway spruce (Picea abies (L.) Karst.). These tree species were valued for their wood properties but also because they reduced forest vulnerability (i.e., probability of tree mortality resulting from a given level of budworm attack; MacLean 1980) to future spruce budworm outbreaks. For instance, white spruce is a favourable host tree for the spruce budworm but its vulnerability to defoliation is much lower than balsam fir because it produces twice as much foliage biomass. On the other hand, black spruce is less vulnerable to spruce budworm defoliation because of its late bud break that causes a phenological mismatch with the budworm larvae (Pureswaran et al. 2015).

Norway spruce, an exotic species in North America originating from Europe and Asia (Holst 1963; Farrar 1995), was largely used in the province of Québec during the last outbreak (Camirand et al. 1983; Blouin et al. 1994). Over 163

\footnotetext{
${ }^{1}$ Université Laval, Faculté de foresterie, de géographie et de géomatique, Département des sciences du bois et de la forêt, Pavillon AbitibiPrice, 2405 rue de la Terrasse, Québec, Québec, Canada G1V 0A6, *richard.berthiaume@sbf.ulaval.ca

${ }^{2}$ Ressources Naturelles Canada, Service canadien des forêts, Centre de foresterie des Laurentides, 1055 rue du P.E.P.S., Case postale 10380 , Québec, Québec, Canada G1V 4C7

${ }^{3}$ Société de protection des forêts contre les insectes et maladies, 1780, rue Semple, Québec, Québec, Canada G1N 4B8
} 
million of trees were planted between 1972 and 1990 (Paradis 1991). Today, numerous Norway spruce plantations are reaching commercial maturity and the resurgence of a spruce budworm outbreak in north-eastern Canada (MFFP 2018) is a reminder that the vulnerability of these plantations to spruce budworm remains unknown. In 2018, 56\% of Norway spruce plantations visited were affected by spruce budworm defoliation compared to $37 \%$ and $36 \%$ for white and black spruce respectively (MFFP 2018). Moreover, several Norway spruce plantations were sprayed with Btk in Québec in 2018 and 2019. Annual defoliation was nearly total (> 98\%) in 2019 in an untreated plantation located in Gaspésie, attesting the need to appraise the risk of the ongoing outbreak for Norway spruce. A good approach to rapidly address this issue is to compare Norway spruce suitability to spruce budworm with that of the indigenous white and black spruce. Host plant suitability refers to "the adequacy of the selected food to sustain growth, survival and reproduction" (Scriber 1984). Biological performance, which is defined in terms of success in insect survival and reproduction (Ochieng'-Odero 1988), provides a good framework to estimate host suitability. Thus, good biological performance of an insect pest on suitable host trees directly influences its population dynamics and thereby increases risk of economic impact.

In this study, we used two life-history traits (weight of pupae and of overwintered larvae) to compare host suitability for the spruce budworm, for three of the most important spruce species used in reforestation programs in the province of Québec. In most Lepidoptera, including the spruce budworm, pupal weight is positively correlated with female fecundity (Miller 1957; Roden and Surgeoner 1991; Awmack and Leather 2002; Berthiaume et al. 2009; Heisswolf et al. 2009), and thus it represents a relevant and widely used variable to assess host suitability for insect fitness. In addition, the size of overwintering eggs of the hemlock looper, Lambdina fiscellaria Guenée (Lepidoptera: Geometridae), has been shown to be linked with winter survival (Rochefort et al. 2011), and this variable appears as a good proxy for insect winter survival. For the first time, we compared the weight of spruce budworm pupae collected in the field on Norway spruce, white spruce and black spruce. We also compared the weight of overwintering spruce budworm larvae $\left(\mathrm{L}_{2}\right)$ produced by parents that had fed on foliage of these three spruce species.

\section{Materials and methods}

Spruce budworm pupae were collected between $7^{\text {th }}$ and $10^{\text {th }}$ July, 2016 from three plantations, each containing one of the following species: Norway spruce, white spruce or black spruce. These plantations were 30 -years-old and were located a few kilometers apart in the Lower St. Lawrence region in Québec, Canada ( $48^{\circ} 31^{\prime} \mathrm{N} ; 67^{\circ} 23^{\prime} \mathrm{W}$ ). Trees of all three species were lightly to moderately defoliated $(<50 \%$ defoliation on current-year shoots), thus reducing the impact of a potential competition between larvae. For each host tree, three to five dominant trees were felled in order to collect current year's shoots containing spruce budworm pupae. Collected shoots of each coniferous species were pooled inside one $80 \mathrm{~L}$ plastic box and shipped to the laboratory within two days.
At the laboratory, pupae were extracted from spruce foliage using fine forceps and placed individually in numbered $29.6 \mathrm{ml}$ solo cups. On the same day, each pupa was sexed and 50 males and 50 females collected from each species were randomly selected and weighed using an electronic balance (Mettler AE163; precision $0.02 \mathrm{mg}$ ) to estimate biological performance on each host tree. Pupae were then reared under controlled conditions in growth chambers $\left(23^{\circ} \mathrm{C}\right.$; $70 \% \mathrm{RH}$ and $16 \mathrm{~L}: 8 \mathrm{D}$ photoperiod) until moth emergence. Once emerged, moths of both sexes were placed inside Plexiglas cages $(60 \mathrm{~cm}$ x $30 \mathrm{~cm}$ x $30 \mathrm{~cm}$ ) for mating with individuals from the same host species. Adult moths were reared at $23{ }^{\circ} \mathrm{C}, 70 \% \mathrm{RH}$ and $16 \mathrm{~L}: 8 \mathrm{D}$ photoperiod. A two dram vial plugged with a piece of cotton wool containing an $8 \%$ watersugar solution (V/V) was always available as a food source to the moths inside each Plexiglas cage. This water-sugar solution was renewed twice weekly as noted in Berthiaume et al. (2009). Straw pieces $(5-\mathrm{cm})$ were placed inside each Plexiglas cage as oviposition substrates for females. At 5-day intervals (shorter than embryonic development at $23^{\circ} \mathrm{C}$ ), plastic straws containing spruce budworm egg masses were collected and placed in petri dishes in which a double layer of cheesecloth was pasted on the lid using paraffin. Petri dishes were maintained at $23^{\circ} \mathrm{C}, 70 \% \mathrm{RH}$ and $16 \mathrm{~L}: 8 \mathrm{D}$ photoperiod inside the same growth chamber. Once hatched, young larvae used the cheesecloth substrate as a refuge in which they could build a hibernaculum in preparation for overwintering and then molt to the second instar without feeding prior to winter. Once all hibernacula were built, petri dishes containing larvae were transferred to a growth chamber and reared for two weeks at $16{ }^{\circ} \mathrm{C}$ (70\% RH and 16 L: $8 \mathrm{D}$ photoperiod). After this period, the temperature was reduced to $10{ }^{\circ} \mathrm{C}$ for an additional week and finally to $2{ }^{\circ} \mathrm{C}$ to maintain spruce budworm larvae in diapause.

To evaluate the influence of host trees on the potential winter survival of the spruce budworm, we carefully removed 80 overwintered larvae from their hibernacula from each host tree and weighed them individually using an electronic microbalance (Thermo Cahn C-33; precision $1 \mu \mathrm{g}$ ) during the first week of November 2016 (between October 31 and November 2). Twelve weeks later, in January 2017 (between 13 and 19 January), 60 other overwintered larvae from each of the three spruce species were removed from their hibernacula and weighed using the same microbalance. These second measures were used to estimate weight reduction of spruce budworm larvae for each tested host tree species.

Finally, to compare tree and spruce budworm phenology, we also collected branch samples in 2018. Twice weekly, one $50-\mathrm{cm}$ branch was taken at mid-canopy from several trees to collect about 50 larvae for monitoring population development. On each branch, 30 current-year shoots were collected to calculate an average shoot development index. Buds and shoots were divided into five stages according to descriptions provided by Michel Auger from the former Ministère de l'énergie et des ressources du Québec, Canada (Dorais and Kettela 1982). These development stages ranged from swollen buds still not open (stage 1) to elongating shoots (stage 5). For each sample date, we averaged shoot stages to produce a shoot development index and we calculated an average budworm larval instar. 


\section{Statistical analysis}

A two-way analysis of variance was performed to compare spruce budworm pupal weight between sexes, host tree species and the interaction between these two main effects. Two-way analysis of variance was also performed to compare the weight of spruce budworm overwintered larvae. In this second model, host trees and period of time (November 2016 or January 2017) were used as main effects and we also tested for interaction between these two factors. When main effects were significant, multiple comparisons of the means were carried out using the LSMEANS statement. Data were not transformed as they met the assumptions for the analysis of variance. All statistical analyses were done with PROC MIXED using SAS (SAS Institute Inc. 1999). For interpretation purposes, we refer to the $5 \%$ alpha probability as the threshold for significance.

\section{Results}

The phenology of Norway spruce and white spruce was similar and much earlier than black spruce (Fig. 1A). Spruce budworm larval development was nearly identical on Norway spruce and white spruce and faster than on black spruce (Fig. 1B) but not to the same extent as tree phenology. The weight of spruce budworm pupae collected under field conditions varied significantly according to spruce species $\left(\mathrm{F}_{2,163}\right.$ $=3.54 ; \mathrm{p}=0.0313)$ and budworm sex $\left(\mathrm{F}_{1,163}=220.18 ; \mathrm{p}<\right.$ $0.0001)$ with no interaction between these two factors $\left(\mathrm{F}_{2,163}\right.$ $=1.44 ; \mathrm{p}=0.2392)$ (Fig. 2). Spruce budworm females were heavier than males and female pupae collected on Norway spruce were significantly heavier than those collected on black spruce $\left(t_{163}=2.82 ; \mathrm{p}=0.0055\right)$. For male pupal weight, no significant difference was detected between host spruce species.

The weight of overwintered spruce budworm larvae was significantly influenced both by spruce species on which parents fed $\left(\mathrm{F}_{2,414}=14.10 ; \mathrm{p}<0.0001\right)$, and by the period during which larvae were weighed $\left(\mathrm{F}_{1,414}=245.32 ; \mathrm{p}<0.0001\right)$. No interaction between these two factors was detected $\left(\mathrm{F}_{2,414}=\right.$ $0.49 ; \mathrm{p}=0.6140$ ) (Fig. 3). Overwintered larvae produced by parents that fed on Norway spruce were heavier than those from black spruce (November: $\mathrm{t}_{414}=3.49 ; \mathrm{p}=0.0005$; January: $\left.\mathrm{t}_{414}=3.94 ; \mathrm{p}<0.0001\right)$, but the difference was not significant between Norway spruce and white spruce (November: $\mathrm{t}_{414}=1.72 ; \mathrm{p}=0.0867$; January: $\mathrm{t}_{414}=1.14 ; \mathrm{p}=0.2551$ ). The period of time at which larvae were weighed also significantly influenced the weight of spruce budworm overwintered larvae $\left(\mathrm{F}_{1,414}=245.32 ; \mathrm{p}<0.0001\right)$. Indeed, larvae weighed at the beginning of diapause (early November) were significantly heavier than those weighed twelve weeks later (mid-January, Fig. 2). Furthermore, larvae coming from parents fed on Norway spruce and white spruce lost $19.5 \%$ of their weight compared to $23.4 \%$ for those from parents fed on black spruce.

\section{Discussion}

This is the first study, to our knowledge, that measured some life history traits for spruce budworm that fed on Norway spruce. This coniferous species was introduced during the last century in North America for its wood properties of rapid growth and wood quality (Holst 1963; Blouin et al. 1994;
Hébert and Thiffault 2015). The spruce budworm is considered as a specialist feeder of the Pinaceae family (Nealis 2016), but its biological performance on North American indigenous spruce is variable. In fact, white spruce is considered as a more favorable host tree for spruce budworm development than black spruce (Blais 1957; Régnière et al. 2012; Berthiaume et al. in press $\left.^{4}\right)$. In this study, pupae collected from Norway spruce were the heaviest among the three spruce species studied. This life-history trait, which is one of the most important to quantify herbivore-host plant relationship (Scriber and Slansky 1981; Roden and Surgeoner 1991), reveals that Norway spruce is highly suitable to the spruce budworm. In fact, we found that the biological performance of the spruce budworm on Norway spruce was similar to that recorded on the highly suitable white spruce (according to Lavallée and Hardy (1988), "white spruce foliage was found to be more favourable to larval development than balsam fir foliage").

As observed in other studies (Scriber and Slansky 1981; Hébert et al. 2006; Berthiaume et al. 2009), variation in host quality does not have the same influence for males and females. In our study, male pupal weight was not significantly influenced by host tree species, while female pupal weight varied according to these hosts. In Lepidoptera, female size is intimately related to the number of offspring produced (Awmack and Leather 2002), and thus it directly influences insect population dynamics. Weight is less important for males as their contribution to the next generation mainly depends on their ability to find females for mating and thus it mainly relates to their flying capacity. Therefore, in general, male size is less influenced by host quality (Berthiaume et al. 2009).

Host suitability can influence offspring production or offspring fitness and has the potential to positively or negatively influence population dynamics (Fox and Czesak 2000; Razmjou et al. 2014). Weight of spruce budworm overwintering larvae indicated that parents that fed on Norway spruce foliage during their larval development produced heavier offspring compared to the two other spruce species studied. Furthermore, larval weight reduction during diapause was less important for Norway and white spruce than for black spruce. Larger overwintering individuals (eggs or larvae) were associated with higher survival to winter conditions in hemlock looper (Rochefort et al. 2011; Vallières et al. 2015) and spruce budworm (Berthiaume et al. in press ${ }^{4}$ ). In fact, the weight of overwintered spruce budworm larvae seems to be a good indicator of their overwintering survival capacity and could become a useful variable to improve models aimed to predict spring larval density of the spruce budworm. Furthermore, in another study (Berthiaume et al. in press $^{4}$ ), we showed that spruce budworm larvae reared on black spruce produced the smallest overwintered larvae when compared white spruce and balsam fir. Future research is needed to better understand the relationship between spruce budworm and Norway spruce and how it may affect bud-

\footnotetext{
$\overline{{ }^{4} \text { Berthiaume, R., C. Hébert, M. Charest, A. Dupont and É. Bauce. }}$ Host tree species related variation and winter conditioning along a climate gradient affect survival of overwintered spruce budworm larvae. Environ. Entomol. in press
} 

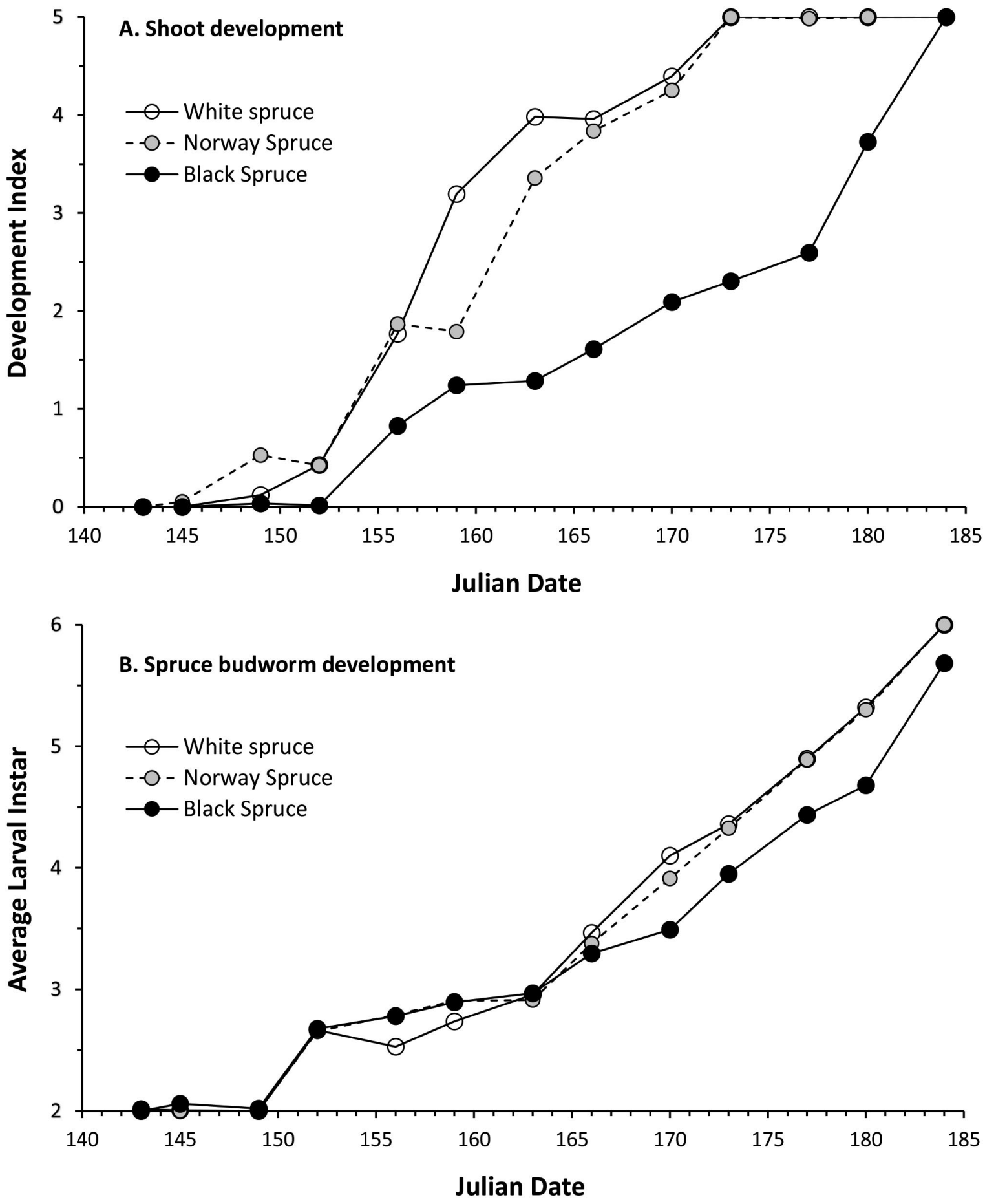

Fig. 1 Average index of shoot development (A) and of spruce budworm development (B) on Norway spruce, White spruce and Black spruce in three plantations in the Lower St. Lawrence region, Québec, Canada 


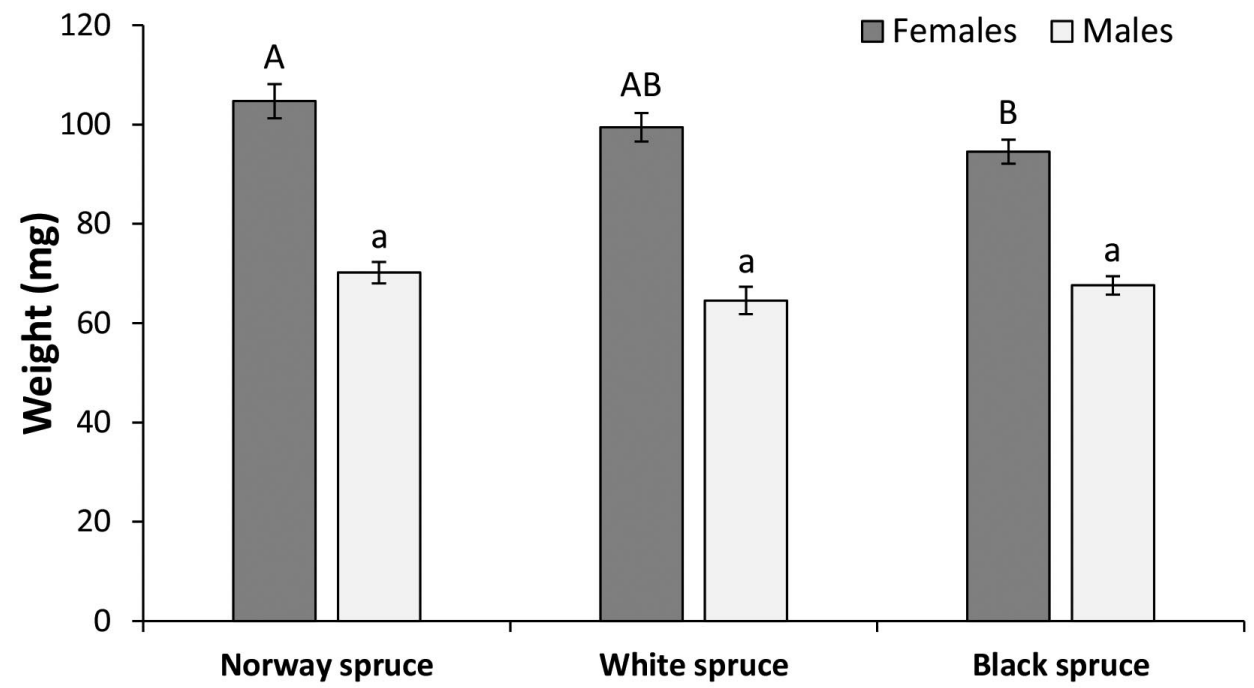

Fig. 2 Spruce budworm pupal weight for females and males collected on Norway spruce, White spruce, and Black spruce trees. Results are expressed, as mean \pm SE. Bars of each tree species followed by different letters are significantly different $(\alpha=0,05)$. Capital and lowercase letters indicate significant differences between sexes

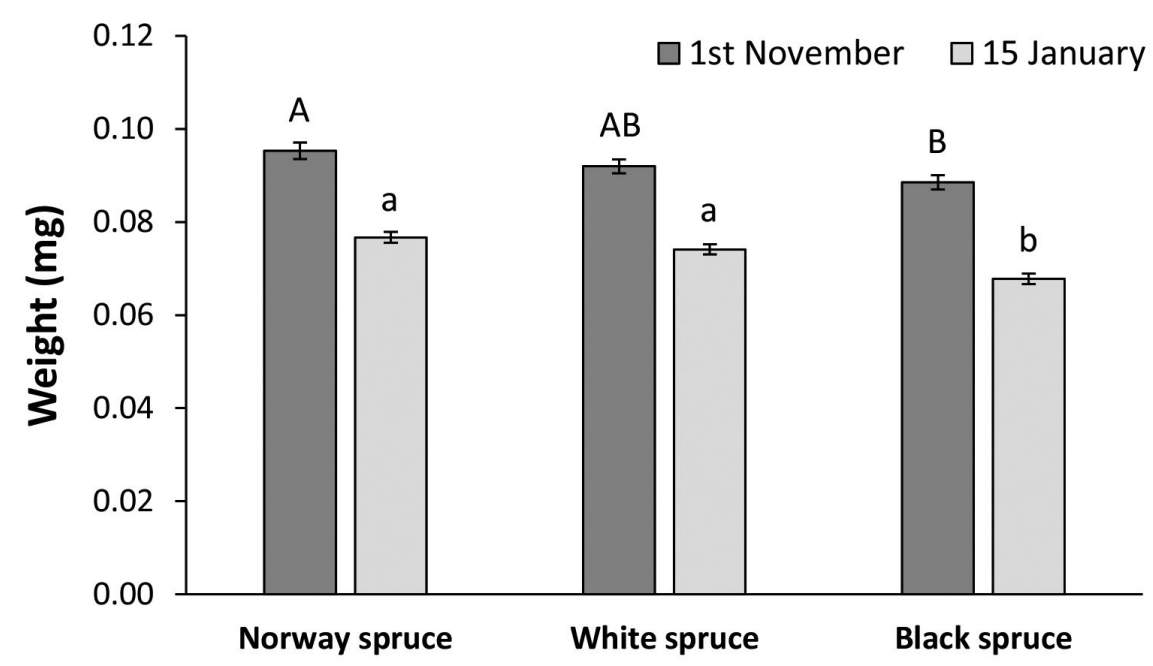

Fig. 3 Weight of spruce budworm overwintering larvae produced by parents that fed on Norway spruce, White spruce, and Black spruce trees. Weight was measured during the first week of November 2016 and during the second week of January 2017. Results are expressed as mean \pm SE. Bars followed by different letters are significantly different $(\alpha=0.05)$ 
age on this new host. Therefore, the protection of Norway spruce plantations from spruce budworm defoliation could become widely needed.

\section{Acknowledgments}

We are grateful to Véronique Rouleau and Elsa Bourgeois from l'Université Laval for their help in rearing spruce budworm. Financial support was provided to the iFor research consortium by the Natural Sciences and Engineering Research Council of Canada (NSERC), Résolu, Arbec, Cédrico, and the Société de protection des forêts contre les insectes et maladies du Québec.

\section{References}

Awmack, C.S. and S.R. Leather. 2002. Host plant quality and fecundity in herbivorous insects. Annu. Rev. Entomol. 47: 817-844. Berthiaume, R., É. Bauce, C. Hébert and J. Brodeur. 2009. Host tree age as a selective pressure leading to local adaptation of a population of a polyphagous Lepidoptera in virgin boreal forest. B. Entomol. Res. 99: 493-501.

Blais, J.R. 1957. Some relationships of the spruce budworm Choristoneura fumiferana (Clem.) to black spruce, Picea mariana (Moench) Voss. For. Chron. 33: 364-372.

Blais, J.R. 1983. Trends in the frequency, extent, and severity of spruce budworm outbreaks in eastern Canada. Can. J. For. Res. 13: 539-547.

Blouin, D., J. Beaulieu, G. Daoust and J. Poliquin. 1994. Wood quality of Norway spruce grown in plantations in Québec. Wood Fiber Sci. 26: 342-353.

Camirand, C., C. Camire and B. Bernier. 1983. Comportement de Picea abies Karst. en plantation au Québec, Canada. Plant and Soil 73: 3-16.

Dorais, L and E. G. Kettela. 1982. A review of entomological survey and assessment techniques used in regional spruce budworm, Choristoneura fumiferana (Clem.), surveys and in the assessment of operational spray programs. Report of the Committee for Standardization of Survey and Assessment Techniques, Eastern Spruce Budworm Council.

Farrar, J.L. 1995. Trees in Canada. Canadian Forest Service, Natural Resources Canada. 502 p.

Fox, C.W. and M.E. Czesak. 2000. Evolutionary ecology of progeny size in arthropods. Annu. Rev. Entomol. 45: 341-369.

Hébert, C., R. Berthiaume, É Bauce and J. Brodeur. 2006. Geographic biotype and host-associated local adaptation in a polyphagous species, Lambdina fiscellaria (Lepidoptera: Geometridae) feeding on balsam fir on Anticosti Island, Canada. B. Entomol. Res. 96: 619-627.

Hébert, F. and N. Thiffault. 2015. Vegetation management, stock type, and scarification effects on white pine weevil incidence and early Norway spruce growth in Québec, Canada. Forest Sci. 61: 966972.

Heisswolf, A., T. Klemola, T. Anderson and K. Ruohomäki. 2009. Shifting body weight-fecundity relationship in a capital breeder: maternal effects on egg numbers of the autumnal moth under field conditions. B. Entomol. Res. 99: 73-81.

Hennigar, C.R., D.A. MacLean, D.T. Quiring and J.A. Kershaw. 2008. Differences in spruce budworm defoliation among balsam fir and white, red, and black spruce. Forest Sci. 54: 158-166.

Holst, M. 1963. Growth of Norway spruce (Picea abies (L) Karst.) provenances in eastern North America. Department of Forestry \# 1022. $15 \mathrm{p}$.
Lavallée, R. and Y. Hardy. 1988. Étude en laboratoire du développement du Choristoneura fumiferana sur l'Abies balsamea, le Picea glauca et le Picea rubens. Phytoprotection 69: 79-86.

MacLean, D.A. 1980. Vulnerability of fir-spruce stands during uncontrolled spruce budworm outbreaks: a review and discussion. For. Chron. 56: 213-221.

MacLean, D.A. 1984. Effects of spruce budworm outbreaks on the productivity and stability of balsam fir forests. For. Chron. 60: 273279.

MFFP 2018. Insectes, maladies et feux dans les forêts du Québec. Direction de la protection des forêts. Québec $53 \mathrm{p}$.

Miller, C.A. 1957. A technique for estimating the fecundity of natural populations of the spruce budworm. Can. J. Zool. 35: 1-13.

Navarro, L., H. Morin, Y. Bergeron and M.M. Girona. 2018. Changes in spatiotemporal patterns of $20^{\text {th }}$ century spruce budworm outbreaks in eastern Canadian boreal forests. Front. Plant Sci. 9: 1905.

Nealis, V. 2016. Comparative ecology of conifer-feeding spruce budworms (Lepidoptera: Tortricidae). Can. Entomol. 148(S1): 33-57. Ochieng'-Odero, J.P. 1988. Aspects of the life cycle, biological performance and quality of the black lyre leafroller 'Cephasia' jactatana (Walker). PhD Thesis, University of Auckland, New Zealand.

Paradis, C. 1991. Programme de surveillance dans les plantations. In: Insectes et maladies des arbres. Service de la protection contre les insectes et les maladies. Ministère des Forêts, Forestry Canada, Laurentian Forestry Centre, Sainte-Foy, Québec, Canada. pp 14-17.

Pureswaran, D.S., L. De Grandpré, D. Paré, A. Taylor, M. Barrette, H. Morin, J. Régnière, and D.D. Kneeshaw. 2015. Climateinduced changes in host tree-insect phenology may drive ecological state-shift in boreal forests. Ecology 96: 1480-1491.

Rauchfuss, J. and S.S. Ziegler. 2011. The geography of spruce budworm in eastern North America. Geography Compass 5: 564-580.

Razmjou, J., B. Naseri and S.A. Hemati. 2014. Comparative performance of the cotton bollworm, Helicoverpa armigera (Hübner) (Lepidoptera: Noctuidae) on various host plants. J. Pest Sci. 87: 29-37. Régnière, J., R. St-Amant and P. Duval. 2012. Predicting insect distributions under climate change from physiological responses: Spruce budworm as an example. Biol. Invasions 14: 1571-1578.

Rochefort, S., R. Berthiaume, C. Hébert, M. Charest and É. Bauce. 2011. Effect of temperature and host tree on cold hardiness of hemlock looper eggs along a latitudinal gradient. J. Insect Physiol. 57: 751-759.

Roden, D.B. and G.A. Surgeoner. 1991. Survival development time, and pupal weights of larval gypsy moth reared on foliage of common trees of the upper great lakes regions. North. J. Appl. For. 8: $126-128$.

SAS Institute Inc. 1999. SAS/STAT ${ }^{\circledR}$ User's Guide. Version 8. Volumes 1, 2 and 3. Cary. NC 3884 p.

Scriber, J.M. 1984. Host-plant suitability. Chapter 7 In: Chemical ecology of insects. William J. Bell and Ring T. Carde (Eds). Chapman and Hall.

Scriber, J.M. and F. Slansky. 1981. The nutritional ecology of immature insects. Annu. Rev. Entomol. 26: 183-211.

Solomon, D.S., L. Zhang, T.B. Brann and D.S. Larrick. 2003. Mortality patterns following spruce budworm infestation in unprotected spruce-fir forests in Maine. North. J. Appl. For. 20: 148-153. Vallières, R., S. Rochefort, R. Berthiaume, C. Hébert and É. Bauce. 2015. Effect of simulated fall heat waves on cold hardiness and winter survival of hemlock looper, Lambdina fiscellaria (Lepidoptera: Geometridae). J. Insect Physiol. 73: 60-69. 